\title{
UN CAPÍTULO DE HISTORIA DE LA NOVELA ESPAÑOLA EN EL SIGLO XVIII: LA NOVELA ILUSTRADA DE PEDRO MONTENGÓN
}

\author{
Isabel Román Gutiérrez
}

Resulta ya casi un tópico hablar de la decadencia, cuando no del vacío o esterilidad, de la novela en el siglo XVIII. La crítica ha señalado una especie de salto entre el siglo XVII y el XIX por lo que a la narrativa se refiere: la novela habia agotado ya sus posibilidades a finales del XVII, y sólo mediante las numerosas traducciones de obras extranjeras - sobre todo, francesas - de los últimos años del XVIII y los primeros del XIX tomará de nuevo fuerza y empuje. No es extraño encontrar, en este sentido, afirmaciones como la de José F. Montesinos, para quien desde mediados del XVII apenas hay novela española que merezca este nombre'.

Es evidente, desde luego, la existencia de un claro menosprecio por la novela como género literario. Señala al respecto Reginald F. Brown que, en los relatos recogidos a lo largo de todo el XVIII, y hasta 1788, no se utiliza el término «novela», sino otros como «historia», «aventuras», «anécdotas», etc. Y cuando aparece se denomina así una obra que no es una novela: se trata del Entusiasmo alegórico o novela original intitulada «Pesca literaria que hizo Minerva de papeles anónimos...», de Domingo Ugena ${ }^{2}$. Todo parece indicar, pues, desinterés y confusión terminológica. Tal desinterés hay que justificarlo como fruto del clasicismo del XVIII, que no acepta un género ignorado por Aristóteles, Horacio y las poéticas clásicas. Esta razón explica también que, incluso en siglos anteriores, la

1 Introducción a una historia de la novela en España en el siglo XIX. Madrid, Castalia, 1982, pảg. 2.

2. La novela española 1750-1850. Madrid, Servicio de Publicaciones de la Dirección General de Archivos y Bibliotecas, 1953, págs. 12-13. 
novela no se considerase sino como obra de entretenimiento fácil, frívola o intranscendente.

Luzán, en su Poética, habla únicamente de la dramática, del poema épico y la epopeya, sin que ninguno de los dos últimos términos puedan identificarse con cualquier tipo de escritos en prosa. Dice Luzán: ...tampoco será epopeya ninguna obra escrita en prosa, por faltarle el esencial requisito del verso. Por «narración» entiende Luzán la manera de disponer el material de la epopeya ${ }^{3}$. Boileau había ya manifestado tanto en su Dialogue des héros du roman (1665) como en la Poétique (1674) su rechazo hacia la novela, género que entiende únicamente como pasatiempo ${ }^{4}$. A ello habia dado lugar la exuberancia imaginativa de la ficción en prosa en el XVII: sólo la novela corta estaba enraizada en cierto realismo. Las exigencias del público, cansado del carácter fabuloso de la novela, se decantan ahora hacia la verosimilitud ${ }^{\text {. }}$.

Poco habian de interesar, en efecto, a los ilustrados dieciochescos, obras que no contribuyeran a realizar la labor pedagógica que tiñe la cultura de todo el siglo. La creación literaria había de supeditarse, como vehículo idóneo para la enseñanza, a las preocupaciones morales y filosóficas que trae consigo la Ilustración. Desde este punto de vista, los géneros narrativos del XVII (novela pastoril, caballeresca, etc.) y sus derivaciones o continuaciones en el XVIII representaban un mundo de fantasía, acción y pasiones desbordadas que habia de resultar perjudicial para la buena formación moral de los lectores. González Palencia recoge, en su Estudio histórico sobre la censura gubernativa en España, 1800-18336, juicios de los censores que, incluso rebasado con creces el 1800, insisten en reprochar a las novelas el ser causantes de la perversión de las costumbres mediante la descripción de aventuras y lances amorosos y pasionales. Ni aun con la declaración de un propósito moralizante obtiene la novela el beneplácito oficial: la censura aducirá que, con el pretexto de corregirlos, se describen expresivamente los vicios.

Del Correa de los Ciegos recoge Montesinos esta afirmación: A pesar de todos los elogios que se han dado a los romances y a los libros de caballerías, confesamos de buena fe que esta lectura divierte a un número muy corto de gentes, es perjudicial a muchos e inútil para todos ${ }^{7}$. Se mantiene viva, en el XVIII, la noción de que la novela es una degeneración de la épica, o, dicho de otra manera, una épica en prosa, noción que deriva, según algún crítico, de una mala interpretación de la criba de libros cervantina ${ }^{8}$. Se trata, entonces, de un género sin entidad ni denominación propias y cargado de connotaciones negativas en cuanto

\footnotetext{
3 Ignacio de Luzán: Poética (ed. de Isabel Cid de Sirgado). Madrid, Cátedra, 1974 (Libro IV, capitulos I y XI, págs. 429 y 469).

4 Referencia tomada de Montesinos, ob. cit., pág. 5.

5 Cf. Aguiar e Silva, Teoría de la literatura. Madrid, Gredos, 1972, pág. 203.

6 Madrid, Tipografía de Archivos, 1934-1941, 3 vols.

7 Ob. cit., págs. 38 .

8 Maurizio Fabbri: Un aspetto dell'llluminismo spagnolo: la opera letteraria di Pedro Montengón. Pisa, Libreria Goliardica, 1972, pág. 43.
} 
a la moralidad se refiere - connotaciones que, por otra parte, habrian de inundar la primera mitad del XIX-

En la segunda mitad del siglo, sin embargo, se lee novela en España. Se trata de una novela de fuertes implicaciones morales e ideológicas, y que, precisamente por ellas, será admirada por los escritores de la época de Carlos III: traducciones de Mme. de Genlis, Lantier, del erudito y enciclopedista Marmontel... Este último, sobre todo, se había convertido en un escritor de moda, cuya lectura y discusión era indispensable en salones y tertulias, admirado por Meléndez Valdés, quien escribía a Jovellanos lo siguiente acerca de las novelas «morales»: Yo esa clase de libros los leo con el mayor gusto, porque nada me embelesa tanto como las máximas de buena moral, esparcidas y como sembradas en una obra llena de imaginación y de primores ${ }^{9}$. La narración se entiende, entonces, como vehículo de enseñanza. Tal fue el éxito de este tipo de relatos, de acuerdo con el espíritu enciclopédico del siglo, que Cadalso, en sus Eruditos a la violeta, satirizaría a los «sabios» que basan en tales lecturas sus conocimientos. Uno de los más difundidos fue Marmontel, de quien Cadalso salvaguarda dos obras: una sátira similar a sus Eruditos... y el Belisario. Dice Cadalso: Aplaudid a Mr. Marmontel. Es el moralista de Estrado más digno de la Cáthedra de Prima. No hay Petimetre, ni Petimetra, Abate distraido, Soldado de Paz, Philósopho extravagante, Heredero gastador, ni Viuda de veinte años, que no tenga un curso completo de moral en los primorosos cuentos de este finisimo Académico. Entre ellos desechad el intitulado el «Philósopho en el nombre». Parece que la tal maldita Novela, Dios me lo perdone, se hizo á drede contra vosotros, pues os viene como zapato de vuestro pie. De buena gana os hablára de otra Obra muy seria de la misma pluma, pero como dicen que sirve solo para Palaciegos desgraciados, Generales tristes, y Ministros caidos y no creo que jamás os veais en eso, me harels el honor de permitirme, que me tome la libertad de callarla ${ }^{10}$.

La concepción de la novela, pues, como los demás géneros, se subordina a criterios didácticos. En ningún otro momento de la literatura española, quizás, esté la creación literaria más directa y explícitamente supeditada a un sistema de valores ideológicos: la poesía ha de ser útil; el teatro, escuela de costumbres; la narrativa posee una misión divulgativa. El XVIII propone, adelantándose a planteamientos ya del siglo XX, la función social que en su entorno han de desempeñar escritor y literatura, recogiendo las formulaciones de Platón. Se hace indispensable entonces, para entender y valorar la producción literaria dieciochesca, tener presentes las relaciones entre literatura e ideología. La efervescencia ideológica de la Ilustración explica, precisamente, y entre otras razones - como el agotamiento del género-, el desprecio del XVIII hacia la novela. Se produce un desajuste entre las inmediatas preocupaciones sociales, culturales, políticas, educativas, etc., y el alejamiento de la realidad que caracterizaba a una novela que, en la decadencia imitativa y falta de originalidad deI XVII, se atenia a unos moldes periclitados.

y Citado por Montesinos, ob. cit., pág. 14.

10 Edición de M. A. Vázquez Medel, facsimilar de la de Madrid, Imprenta de Sancha, 1772 (Sevilla, Alfar, 1982, pág. 32). 
Carlos Reis, en su trabajo Para una semiótica de la ideología, recoge y acepta la noción de ideología propuesta por Guy Rocher: un sistema de ideas y juicios explicito y generalmente organizado, que sirve para describir, explicar, interpretar o justificar la situación de un grupo o de una colectividad y que, inspirándose generosamente en valores, propone una orientación precisa a la acción histórica de ese grupo o de esa colectividad ${ }^{11}$. Si tenemos en cuenta que la literatura puede convertirse en un medio eficaz para proporcionar a la sociedad una determinada orientación ideológica, habrá que conceder importancia, como indica Reis, al estudio de la ideología en cuanto universo de sentidos proyectados sobre los discursos artísticos y en particular sobre el discurso literario (...). No se trata ya de leer la literatura como puro documento económico-social; se trata ahora de observar la interacción dialéctica entre sentidos ideológicos y estrategias discursivas $^{12}$. Si esto es así, resulta evidente que un sistema ideológico concreto puede predeterminar las formas y maneras de la producción literaria, La explicitación y «realización» de ese conjunto de ideas y valores en una actividad socio-cultural efectiva como lo es la creación literaria permite insertar el sistema ideológico en un marco concreto, permitiendo a dicho sistema desempeñar su función de una manera real y directa.

$\mathrm{Y}$ esto ocurre en periodos ideológicos consistentes, como el siglo XVIII, en los que, señala Reis, la consistencia se intuye como factor de redundancia semántica en la obra literaria (...). La novedad tiende a producirse sobre todo en el nivel de los procedimientos de manifestación ideológica, esto es, de las soluciones técnico-discursivas que plasman sentidos ideológicos ya consagrados. Apuntaba con anterioridad que, si las soluciones discursivas se insertan en el marco de una actividad, la literaria, consagrada en la tradición cultural como no inmediatamente utilitaria, han de recurrir a un instrumental técnico-literario variablemente sofisticado, pero muy rico en recursos: modos, géneros y subgéneros literarios, elementos simbólicos, artificios estilísticos, procedimientos retóricos, articulaciones técrico-narrativas, elaboraciones temáticas, etc. etc. En una palabra, todo aquello que en buena parte preserva la utilidad de la obra literaria, además de las contingencias históricas inherentes a su información ideológica ${ }^{13}$.

En el siglo XVIII, sin embargo, y sobre todo en su segunda mitad, la presión ejercida por el sistema ideológico es tal $-\mathrm{y}$ ello motivado en parte por la actividad político-social de los hombres de letras de la época- que concede a la actividad literaria una función inmediatamente utilitaria: el instrumental técnico-literario habrá de supeditarse a esta función, quedando relegado a un segundo plano y seleccionado en virtud de su efectividad. Esta preponderancia determina, por un lado, la redundancia semántica; por otro, la elección de determinados recursos que no van dirigidos a encubrir o revestir las características del mensaje, sino a favorecer su comprensión. Podrían explicarse así las repetidas acusaciones de pro-

11 Guy Rocher: Introducción à la sociologie générale. L'action sociale. Paris, éditions HMH, 1968, pág. 127. Carlos Reis: Para una semiótica de la ideologia. Madrid, Taurus, 1987, pág. 21.

12 Ob. cit., págs. 13-14.

13 Idem, págs. 29 y $22-23$ 
saísmo, vacio literario, etc., que recibe el siglo de las luces: se trata de una literatura eminentemente divulgativa, que ha de desempeñar un papel didáctico y utilitario. Se justifica también que los recursos utilizados, y la misma concepción de la literatura, vayan encaminados a proporcionar algún deleite a las secas advertencias de índole ideológica, de forma que éstas puedan ser debidamente asimilidas y aprovechadas. El mensaje tenderá, además, a la sencillez codificadora y a la claridad expositiva para permitir su fácil intelección, con el consecuente empobrecimiento «retórico».

Resulta esclarecedor, en este sentido, recurrir también al concepto de «obra abierta» postulado por Umberto Eco: una obra abierta es aquella susceptible de recibir múltiples interpretaciones que dependen, sobre todo, del receptor ${ }^{14}$. Según esto, una «obra abierta» podría hacer perder eficacia a un mensaje ideológico en tanto en cuanto que la plurisignificación, al disponer de un amplio margen interpretativo, puede desviar al lector del sentido que se le pretende imponer. Por el contrario, si el discurso deja ver con transparencia sus pautas ideológicas, la "apertura» disminuye, puesto que el sentido se infiere univocamente desde el principio. La inserción de la producción literaria del XVIII en su preciso marco ideológico permitirá, entonces, suponer su carácter «cerrado» y unívoco, no pluriinterpretativo o plurisignificativo.

Hay que considerar además que una literatura predeterminada en su carácter y recursos técnicos por condicionamientos ideológicos deberá tener en cuenta, sobre todo, al receptor. En este sentido, cabría pensar que uno de los géneros más adecuados para la exposición ideológica sería la narrativa, puesto que permite al narrador explicitar, rebatir o confirmar con su juicio, de un modo directo, las conclusiones desprendidas de su exposición.

Sin embargo, la eficacia didáctica de la narrativa no fue entendida ni aprovechada en el siglo XVIII salvo por contados autores, con toda seguridad debido a los prejuicios aludidos con anterioridad que devienen de la tradición novelística áurea. De ahí que no se teorice en el siglo abiertamente sobre la novela, siendo posible sólo encontrar esporádicas referencias de algunos autores acerca del género; de ahí también el desinterés - ejemplificado por Luzán- o la confusión terminológica.

Cabria plantearse, sin embargo, por qué el desdén de los ilustrados hacia los excesos del teatro barroco provoca una reacción en la dramática dieciochesca y no ocurre de igual manera en la narrativa. Aunque éste es un tema que no trataré aquí, podria señalarse que la agilidad que proporciona la escenificación teatral no resultaría fácil de conseguir en la novela sin caer en los mismos recursos que se venían criticando, esto es, sin recurrir a la invención y la fantasía, propias de los moldes de la novela pastoril o la bizantina que, según Ferreras, perduran en el XVIII ${ }^{15}$. La tradición narrativa no aceptaba, por otra parte, la moralina que ya desde el XVII venía inundando la novela, y que frena toda posible innovación y reestructuración. A esto hay que añadir, además, la extraordinaria popularidad y arraigo del teatro en las clases populares y el hecho de que desde antes del XVIII

14 Obra abierta. Barcelona, Ariel, 1984, págs. 74 y 98.

15 La novela en el siglo XVIII. Madrid, Taurus, 1988, pág. 23. 
viniera utilizándose como uno de los medios más eficaces para imponer una ideología.

Será a partir de la década de 1780 , y gracias a la influencia de las obras de Radcliffe, Richardson, Goethe, Chateaubriand, Rousseau..., cuando se empiecen a escribir novelas basadas en estos modelos, que originarán un cambio sustancial con respecto a la tradición española: Valladares y Sotomayor, Mor de Fuentes, Martínez Colomer... La moral y la sensibilidad pasan a convertirse, siguiendo la influencia europea, en los elementos novelísticos fundamentales, mezclándose el didactismo con la emoción prerromántica.

En este contexto, resulta inexcusable reconocer la importancia del esfuerzo de Pedro Montengón, un novelista hasta hace poco olvidado y que intentan reivindicar el estudio de Maurizio Fabbri y la reciente edición de su novela Eusebio llevada a cabo por Fernando García Lara ${ }^{16}$. Tanto este crítico como Maurizio Fabbri coinciden en señalar que la crisis narrativa del XVIII se ha convertido ya en un lugar común de la crítica, que, según esta idea, se empeña en ignorar a Montegón mientras pone de relieve, por ejemplo, la figura de Isla ${ }^{17}$.

Montegón publica, entre 1786 y 1795 , cinco novelas de diferentes características. Es el primer autor español que, en el siglo XVIII, se plantea la problemática del género y busca nuevas vias de recuperación o de renovación: novela educativa, sentimental, pastoril, heroica, histórica... Con ello demuestra Montegón la consciencia de la necesidad de renovar la narrativa y sus conocimientos de las diversas técnicas novelísticas, por una parte; por otra, es el único novelista que se da cuenta del valor pedagógico que posee la novela como vehículo propagandístico e ideológico: de ahí su insistencia en ella.

En efecto, Montengón, jesuita expulsado de España y exiliado en Italia, es un perfecto ilustrado. Conocedor de la cultura clásica e interesado por diversos aspectos del progreso social y económico, posee una insaciable curiosidad enciclopédica y un afán divulgativo muy acordes con el espíritu de su época. Todo ello se muestra en la variedad de géneros que cultivó y en la diversidad de los registros narrativos que aborda, pero también en una obra que responde de modo muy claro al enciclopedismo del siglo: se trata de las Frioleras eruditas y curiosas para la pública instrucción, publicadas en 1802. Aborda en esta miscelánea los más diferentes temas (mitología, agricultura, mineralogía, ciencias...) haciendo gala de una amplia erudición clásica y científica a la vez que muestra su afición por las cuestiones pintorescas y curiosas y, desde luego, su empeño por divulgar la ciencia y la cultura. Dice Montengón en el prologo: El estudio, que es el solo que puede proporcionar la instrucción y destruir en parte la nativa ignorancia del hombre, no es para todos, porque no a todos se lo permite su estado, y exige de aquellos que pueden dedicarse a él, tanto tiempo y tesón que casi excluye de su esfera cualquiera otro trabajo y aplicación ${ }^{18}$. Para extender el conocimiento a aquéllos que no pueden acceder al estudio escribe Montengón su obra.

16 Eusebio (ed. de Fernando Garcia Lara). Madrid, Editora Nacional, 1984. Citaré en adelante por esta edición.

17 Fabbri, ob. cit., págs, 41-42.

18. Madrid, Atlas (colección «Cisneros»), 1944 (nota preliminar por Joaquín Rodríguez Arzúa), pảgs. 15-16. 
En su faceta poética, en la que no voy a detenerme aquí ${ }^{19}$, hay que considerar también a Montegón como un auténtico ilustrado que se anticipa quizá a los poetas españoles al conceder un sentido exclusivamente didáctico y filosófico a su poesía. En 1779 publica las Odas de Filopatro (seudónimo que hace alusión a un patriotismo exacerbado desde su exilio italiano, patriotismo que, como veremos, habrá de ser matizado). En las Odas se incluyen poemas históricos, filosóficos, patrióticos, bíblicos, traducciones de Horacio, elogios a personajes políticos, etc.: un auténtico muestrario de poesía ilustrada.

También fue Montengón autor teatral, aunque con poca fortuna, pues el editor Sancha no aceptó sus obras y han permanecido inéditas. Los títulos de las comedias, no obstante, permiten deducir su orientación ilustrada (La Matilde, El impostor arrepentido, Los ociosos, El avaro enamorado) y los de sus tragedias - adaptaciones de Alfieri y Séneca, según Fabbri- remiten al gusto neoclásico ( $A g a$ memnón, Egisto y Clitemnestra, Edipo, Emón y Antígona) ${ }^{20}$.

Y cabe destacar, antes de abordar su producción novelística, otro aspecto más de su actividad literaria que posee singular importancia: traduce, en 1800, bajo el título de Fingal y Temora, parte de la obra poética del supuesto Ossián de Macpherson ${ }^{21}$. Ello demuestra que Montengón está al corriente de las tendencias prerrománticas europeas, algunas de cuyas características, sobre todo el sentimentalismo, habrán de aparecer en sus novelas.

Comienza Montengón su andadura novelística con la que, curiosamente, y a pesar de ser la primera, le proporcionó más exito — se siguió reeditando hasta mediados del XIX - y se considera su mejor obra: el Eusebio, publicada entre 1786 y 1788 . Se trata de una novela educativa inspirada en el Emilio de Rousseau, pero en la que la crítica ha encontrado también otras fuentes ${ }^{22}$. La preocupación educativa, pretexto además para exponer muy diversos temas, se inserta, desde luego, en la corriente del pensamiento europeo del siglo XVIII. Hardyl, preceptor de Eusebio, se basa tanto en la filosofia de Séneca y Epicteto como en pensadores europeos del XVII y XVIII cuyas ideas fueron muy difundidas. Con un rechazo absoluto de Aristóteles y la escolástica, las máximas de Epicteto sirven como lección diaria a Eusebio en su niñez y adolescencia; en su juventud, Hardyl

19 Se han ocupado de su obra poética Fabbri, en su citado estudio, y Joaquin Arce en La poesia del siglo ilustrado (Madrid, Alhambra, 1980, especialmente las págs. 257-260).

20 Según noticia de una carta del propio Montengón a Sancha recogida por González Palencia: "Pedro Montengón y su novela El Eusebio», en Entre dos siglos. Madrid, C.S.I.C., 1943, págs. 137-180. pàg. 147. Cf. además Fabbri, ob. cit, págs. 151 y ss.

21 Fingal y Temora. Poemas épicos de Osián, antiguo poeta céltico. Madrid, Oficina de don Benito Garcia y Compañía, 1800. El ejemplar manejado consta como tomo I; no conozco ningún tomo más. Es de suponer que fue el único. Reproduce el «Prólogo del traductor inglés» (MacPherson) y se atiene a la versión italiana del abate Cesarotti.

22 Así, para Jeanne Isaac está también detrás La nueva Eloísa, de Rousseau; para Caso hay que tener en cuenta numerosas fuentes, tanto hispánicas como no hispánicas: Vives, los humanistas españoles del XVI, Cervantes, Gracián, Isla, Feijoo... (J. Isaac, «Les vicisitudes, de 1786 à 1851, d'un roman rousseauiste en Espagne: Eusebio, de Pedro Montengón», tesis doctoral inédita, Universidad de Burdeos III, 1978. Cito por J. Caso González, «Montengón», en Historia y crítica de la literatura española, t. IV: llustración y neoclasicismo. Barcelona, Critica, 1983, pág. 589). 
le proporcionará el conocimiento de Séneca ${ }^{23}$ y Locke. Además de estos autores, aludidos explícitamente, hay que señalar la influencia filosófica de Bayle, que rechaza una religión particular como verdad única (algo que puede observarse en el prólogo de Eusebio, al que haré referencia), y Wolff, que propone el origen racional, y no divino, de la moral ${ }^{24}$.

En efecto, conceptos diferentes a los estrictamente religiosos conforman la moral europea del XVIII. Paul Hazard señala como virtudes fundamentales la tolerancia, la beneficencia y la humanidad. Entiendo que las dos primeras, manifiestas explicitamente en el Eusebio, vienen a sustituir al fanatismo religioso y al concepto cristiano de caridad, respectivamente. En cuanto a la humanidad, Hazard indica que se trata de la virtud por excelencia para los moralistas del siglo $X V I I I$, puesto que les recordaba esa condición de hombre de la que pensaban que habia que partir siempre, a la cual habia siempre que volver y que, por consiguiente, lo encerraba todo ${ }^{25}$. El hombre es el objeto de este libro, son las primeras palabras que pueden leerse en el prólogo de Montengón a Eusebio. Y sigue: las costumbres y las virtudes morales son el cimiento de su religión. Católico, la tuya es sola la verdadera, sublime y divina; mas tú no eres solo en la tierra y el «Eusebio» está escrito para que sea útil a todos. Por eso, Montengón pretenderá exponer, según sus palabras, la virtud moral desnuda y sin los atributos de la cristiana (págs. 79-80). Tras una pequeña concesión a la posible censura, hay, pues, una confesión de tolerancia y eclecticismo. Curiosamente, los protagonistas de Eusebio pertenecen a la secta cuáquera, a la que en repetidas ocasiones se califica como sencilla y tolerante. Frente a esta tolerancia, en otras ocasiones se alude a las desastrosas consecuencias a las que puede llevar, como en el caso de las guerras de religión europeas, el fanatismo religioso, incluido el católico. Tales ideas se insertan perfectamente en el pensamiento ilustrado europeo, como se inserta también Cadalso al reconocer como única religión universal la «hombría de bien's.

Pero la exposición de su pensamiento le acarreó a Montengón serios problemas con la censura, y estos problemas repercutieron de modo considerable en la segunda edición de la novela, sustancialmente distinta ${ }^{26}$, y también en las dos últimas partes de la primera edición, que Montengón tuvo que ir modificando a medida que se iba publicando la novela, desequilibrándola y perjudicando, claro está, su coherencia ideológica. Hay que entender entonces como más fiel a la intención primera de su autor la primera edición, teniendo en cuenta además que sería difícil deslindar las modificaciones del propio Montengón de las del censor.

23. Alarcos Llorach recoge todas las referencias a Séneca en el Eusebio ( «El senequismo de Montengón», en Castilla, 1, 1 (1940-1941), págs. 149-156). 40-45.

24 Cf. Paul Hazard, El pensamiento europeo en el siglo XVIII. Madrid, Alianza, 1985, págs.

25 Idern, págs. 153-155.

26 Véanse, al respecto de los problemas de censura del Eusebio, los trabajos de A. González Palencia (cit.) y M. Teresa Marzilla («Las dos redacciones del Eusebio de Montengón», en Revista de Archivos, Bibliotecas y Museos, LXXVII, 1 (1974), págs. 335-345). 
El propósito de Hardyl es instruir a Eusebio en la «ciencia moral», cuyo objeto es, dice Montengón por boca del narrador, purificar los sentimientos y afectos desordenados, como es fin de las otras ciencias y estudios purificar los errores y preocupaciones falsas del entendimiento (pág. 678). El conocimiento de esa ciencia moral exige un esfuerzo de la voluntad y de la razón, y ésta proviene directamente de la naturaleza. Se trata, entonces, de postular una religión natural, que hay que relacionar con la importancia concedida a la naturaleza en el siglo XVIII. Según Hazard, se convierte en una palabra talismán que hay que añadir, en la ideologia del siglo, a otras palabras no menos importantes: la razón y las luces; es más: la naturaleza se convierte en fuente de las luces y garantía de la razón. El hombre debe entonces someterse a la naturaleza. Se implanta una religión natural y, en consecuencia, un deísmo depurado de todo culto exterior y toda secta que reconoce únicamente la existencia de un primer ser; todo lo demás es accidental ${ }^{27}$. Tal es la religión y la moral que Hardyl quiere para Eusebio, para el hombre, integrándose plenamente en el pensamiento europeo.

Alguna precisión, sin embargo, hay que hacer al respecto. Frente a la bondad innata que la naturaleza, según Rousseau, concede al hombre, Montengón matiza: el hombre nace con virtudes y con vicios. De la educación moral y del contacto con la naturaleza depende que florezcan las primeras. Dice el narrador: Eusebio era vano, astuto, ambicioso, pusilánime, soberbio, envidioso. Tenía todos los defectos que contrae el hombre desde la cuna. ¿Ha desarraigado Hardyl tales vicios? No; esto es imposible en la naturaleza del hombre, pues si fuera posible no necesitariamos entonces de virtud, pero bien si hales disminuido las fuerzas, las ha sujetado y rendido. Más adelante, especifica que los vicios mismos son rudos, por decirlo así, en sus principios ninguno nace malvado. Mas a fuerza de ejercitarse el hombre en el mal, va contrayendo la costumbre de ser malo, hego perverso, inicuo, monstruo (págs. 214-215). Y es el contacto con la civilización el que hace al hombre malo: el contacto con la naturaleza jamás le hubiera pervertido. Señala Fabbri, que frente a Rousseau - y reconociendo la semejanza entre sus obras y el idéntico fondo estoico-, que educa a Emilio, puesto que el hombre es bueno por naturaleza, para integrarse perfectamente en la sociedad humana, Montengón propone una educación para Eusebio que le permita defenderse de esa sociedad, aunque intentando serle útil, basándose en la indiferencia del alma ante las contrariedades de la vida y en el aislamiento en la naturaleza ${ }^{28}$. Tales modificaciones con respecto al pensamiento rousseauniano, presentes a lo largo de toda su obra, podrían interpretarse también como una concesión a la censura, puesto que no niega el dogma del pecado original.

Los condicionamientos externos de índole ideológica fueron más importantes en el Eusebio, influyendo en su estructura y haciendo peligrar su coherencia. En la moral natural se educa el personaje a lo largo de las dos primeras partes de la novela. A la tercera le precede una justificación del autor, que ruega a los que echan de menos la religión en las primeras partes del «Eusebio» que tengan

27 Ob. cit., págs. 105-106.

28 Ob. cil., págs. 72-73. 
en suspensión sus quejas hasta la cuarta parte, en que verán suplido con ventajas este defecto (pág. 554). Ya en el primer libro de esta tercera parte alude Eusebio a las enseñanzas del Redentor, y pone Montengón una nota en la que se percibe cierta ironía: Gracias a Dios que Eusebio comienza a dar a entender en este lance que está imbuido de las máximas de la divina sabiduria (págs. 597). La referencia es absolutamente extemporánea, habida cuenta de que ni Hardyl ni el narrador han hecho mención jamás de cuestiones religiosas. Más forzada aún resulta la repentina conversión y arrepentimiento de Hardyl a la hora de su muerte. Para tranquilizar su conciencia, ha de confesar a Eusebio que a pesar de todas las máximas de la filosofía, triunfa la religión en toda su terrible majestad y ésta le obliga a detestar las erradas máximas que alimenté en mi pecho por tantos años y que me indujeron a escoger la Pensilvania [lugar de asentamiento de los cuáqueros] por asilo seguro de la libertad de conciencia que deseaba en mi error, para conformarme con la virtud natural, creyendo hallar en ella una vida y muerte dichosa. Para contentar a los censores, hace constar que su alma está preparada para la religión por el ejercicio de la virtud, y que nada se ha podido observar en su doctrina contrario a la religión. A pesar de ello, se ve obligado a advertir a Eusebio: ...pudiera tal vez alguna de mis máximas, sin advertirlo yo, engendrar en tu ánimo la indiferencia culpable a que insensiblemente me acostumbraron mis mismas dudas sobre la fe, y especialmente el aprecio tal vez, sobrado que manifesté a la doctrina de los antiguos filósofos... (págs. 795-796). El contrasentido es evidente: habría sido errada, según esto, la educación de Eusebio a lo largo de casi ochocientas páginas. Las alusiones posteriores a la religión, en la cuarta parte de la novela, son escasas, sobre todo si se tiene en cuenta la densidad ideológica y las largas disertaciones dedicadas con anterioridad a la virtud natural: Eusebio sustituirá la lectura de los filósofos por la del Evangelio; adoctrina a uno de sus amigos y habla a su mujer, cuáquera, de la religión católica y, por último, el mismo narrador, para evitar suspicacias, asume la defensa de la religión en el libro tercero.

A todas luces tales justificaciones fueron insuficientes, pues el libro fue censurado por defender a los cuáqueros, por la inmoralidad de las relaciones amorosas y por el relato de un incipiente incesto. Evidentemente, la Inquisición intentaba evitar a toda costa la exposición, escasamente disimulada, de las doctrinas europeas. Como acertadamente señala Marzilla, la Inquisición se preocupa ahora, sobre todo, de obstaculizar las doctrinas de la Ilustración filtradas por Francia; consecuencia de esto es, entre otras cosas, buena parte de la interpretación en clave cristiana de estas doctrinas, efectuada por casi todos los intelectuales españoles de este siglo y por el propio Montengón ${ }^{29}$.

Una doctrina, pues, la de Montengón, aunque obligadamente matizada, enraizada en la ilustración europea. También lo están sus teorías sobre la educación. Hazard refiere, como propias del pensamiento europeo del siglo ilustrado, determinadas preocupaciones educativas: el desprecio hacia la escolástica y Aristóteles, la necesidad de aprender a la vez un oficio, diferentes lenguas y ciencias (Eusebio realizará todo este aprendizaje y será cestero de oficio), la conveniencia

29 Art, cit., pág. 336, nota 7 . 
de comenzar la educación desde la cuna (como hará Eusebio con su hijo) y de tener en cuenta a la vez la educación fisica (Eusebio se ejercitará en las labores agricolas y aprenderá a nadar), etc., ideas que provienen de la filosofía de Locke ${ }^{30}$. La intención educativa permite entonces abarcar un amplio repertorio de teorias ilustradas. Indica con acierto García Lara que las noticias sobre las más diversas materias (...) hacen del «Eusebio» un enciclopédico muestrario de conocimientos que mucho debieron de aplaudir los lectores de su tiempo ${ }^{31}$.

En efecto, todos los temas que preocupaban a los ilustrados tienen cabida en la novela: el duelo, el lujo, la influencia del clima, la autoridad paterna, la medicina, la esclavitud, el suicidio, el cuidado de los recién nacidos, la reforma agraria, la prostitución, el matrimonio, la historia, las ciencias y las letras... La pretensión del libro no es ya sólo proponer un modelo específico de educación, sino también contribuir a la difusión de los conocimientos y sacar al pueblo de sus errores. De ahí también el frecuente tratamiento de la superstición popular, fruto de la ignorancia. Cabe destacar, en este sentido, el descubrimiento, por parte de Hardyl y Eusebio, de la superchería del supuesto milagro del beato Paris, versión novelada de un hecho real al que Hazard alude ${ }^{32}$.

Muchos de estos temas son abordados también por los ilustrados españoles: las Cartes marruecas de Cadalso, que responden al mismo afản enciclopedista; el Informe sobre la ley agraria, de Jovellanos o El delincuente honrado, en el que se aborda el tema de la justicia y el duelo; El si de las niñas de Moratín sobre la legitimidad de la autoridad paterna, por no poner más que unos ejemplos significativos. Montengón ha de ser entendido, pues, como un perfecto ilustrado, al corriente - quizá más que los otros ilustrados españoles- de las tendencias europeas pero en modo alguno desvinculado de la realidad española a pesar de su exilio.

Escribe, en primer lugar, siempre en castellano, lo que le ocasionó, debido al deterioro de su idioma natal por su prolongada estancia en Italia, constantes críticas. De hecho, el impresor Sancha, a petición de los censores y con el consentimiento del autor, hacía que sus obras fuesen corregidas. De este problema se hace eco Montengón en la novela: tanto Hardyl como Eusebio se preocupan por perfeccionar su lengua, este último para purificarla de los resabios que hubiese podido contraer de las otras lenguas extranjeras que hablaba y que sabía (pág. 840 ), mostrando una clara preocupación purista que no era ajena a la de los españoles (recuérdese la sátira a los galicismos en las Cartas marruecas, por ejemplo).

Pero, además, Montengón se preocupa especialmente por los problemas españoles. Trata de justificar, en primer lugar, el descrédito de España en el resto de las naciones ilustradas, representado en la novela por las siguientes acusaciones de unos ingleses: La nación española cayó en tal letargo que tendrá para siglos (...). Parece que Felipe Segundo dio a beber adormideras a los españoles (...). Es cosa que saca de tino que una nación imperiosa, que acababa de amedrentar

30 Ob. cit., págs. 171-179.

31 Introducción a la edición citada, pág. 58.

32 Ob. cit., pàg. 95. 
a toda Europa, haya caído en tal letargo y tan universal que todo se resiente de esa misma desidia: ciencias, artes, comercio, náutica, agricultura, en fin, todo. (..) No [hay] ni soldados, ni generales, ni literatura, ni valor y (...) los frailes lo [han] avasallado todo a la devoción y escapularios (págs. 517-518). Tras esta critica ilustrada a la política de los Austrias y al fanatismo religioso, los protagonistas matizan: esta opinión se debe también a la rivalidad entre naciones - que envidian a España el descubrimiento-, sin quitar por ello importancia a las aspiraciones imperialistas de Carlos I, la arrogancia de los españoles y el empeño de Felipe II en avasallar Flandes (págs. 522-523).

No oculta Montengón sus críticas. Nada más entrar en España, constata su retraso con respecto a otras naciones de Europa, y esto tanto en las cuestiones que afectan al progreso (estado de los caminos y mesones, abandono de la agricultura) como las relativas a la cultura (la enseñanza obsoleta y escolástica de las universidades de Alcalá y Salamanca) (págs. 757 y ss., 769 y ss.). Se trata de una crítica ilustrada al pais, a pesar de la confesión emocionada de patriotismo - que matizaría Montengón más tarde- manifestada en el júbilo de los protagonistas al pisar tierra española. Miguel Batllori explica el nacionalismo exacerbado de los españoles del grupo de los jesuitas expulsos en Italia como reacción contra el incipiente nacionalismo italiano, antiespañol en su misma esencia ${ }^{33}$. Esto explicaría también la ausencia de alusiones a Italia, país cuya referencia excusa Montengón con un pretexto intradiegético: Eusebio y Hardyl deben adelantar la resolución de sus negocios en España y volver a América a causa de la enfermedad de Leocadia, prometida de Eusebio.

Tampoco se encuentran referencias a la literatura francesa e inglesa, cuya ausencia sería de extrañar, dado que sus influencias son evidentes en el Eusebio. Alude exclusivamente al teatro de Shakespeare ${ }^{34}$, achacando a su teatro los mismos defectos que se atribuían en el siglo a la literatura barroca en general. Montengón se centra, sobre todo, en la literatura española, manifestando el mismo desprecio, como buen ilustrado, hacia nuestra literatura barroca. Eusebio, para perfeccionar la lengua española, escoge una serie de obras. La poesía barroca (romances, letrillas, silvas, jácaras, sonetos) son todo hojarasca que destinó para el fuego. Sus preferencias se decantan, en este orden, por los Argensola, Garcilaso, Fray Luis de León y Herrera, Villegas. No explicita sus opiniones sobre la comedia, en la que dice guiarse por el gusto de su amigo Eugenio. De tragedias no encuentra modelos dignos de atención. Por lo que se refiere a la prosa, escoge el Lazarillo; prefiere todas las demás novelas de Cervates al Quijote; la República literaria de Saavedra Fajardo, las obras jocosas y serias de Quevedo y la ascética de Fray Luis de León, Fray Luis de Granada, Santa Teresa y Rivadeneyra (págs. 841-842).

Resulta evidente, tras este repaso del Eusebio, que nos encontramos ante una novela especificamente ideológica. Todos los datos que demuestran la condición

3) La cultura hispano-italiana de los jesuitas expulsos. Madrid, Gredos, 1966, pág. 16.

34 Alarcos Llorach comenta las alusiones de Montengón al texto ( $₫$ Montengón, el Hamlet y nuestra literatura del siglo de Oro», en Castilla, I, I (1940-1941), págs. 157-160). 
ilustrada de Montengón, tanto en su contexto europeo como en el español, sirven también para caracterizar su obra: se trata de una novela ilustrada y de pretensiones enciclopédicas. Esta condición le ocasionó un éxito inmediato. Ahora bien, ¿es ésta la única causa de su popularidad? Elena Catena afirmaba en 1947 que el Eusebio no debe su fama a la forma literaria, sino que todo su éxito en el siglo $X V I I I$, prolongado durante toda la primera mitad del XIX, se debe a la curiosidad que despertaban las ideas expuestas en él. Más tarde matizaría, rechazando también como causa de su popularidad la prohibición de que fue objeto por parte de la censura y atribuyéndola a su manera de exponer y divulgar, con ropaje novelesco, ideas enciclopedistas europeas y sentimientos y opiniones de los ilustrados españoles ${ }^{35}$. Caso González, por su parte, basa el éxito de la novela, precisamente, en su forma literaria, que, según el crítico, aún no ha sido estudiada. Recoge, a tal efecto, el juicio de Juan Andrés: Sólo diré en general que es recomendable la invención y mucho más el estilo, y sólo que la verosimilitud y naturalidad de los hechos, el modo de referirlos y lo bien expresado de los caracteres con otras buenas prendas de este romance lo hacen leer con gusto, interés y utilidad $^{36}$.

Entiendo que no deben desdeñarse ninguno de estos factores. De un lado, y como ya hemos visto, los temas tratados en el Eusebio son de plena actualidad y difunden ideas del pensamiento europeo; qué duda cabe de que la larga historia inquisitorial de la novela despertaria también la curiosidad de sus contemporáneos. Pero, además, hay que tener en cuenta que un libro que pretende difundir una doctrina moral y un amplio conjunto de materias enciclopédicas lo hace bajo forma novelada, tratando de conjugar lo útil con lo deleitable. Lo que pretendo hacer a continuación es recoger la sugerencia de Caso y detallar, aunque brevemente, algunos aspectos técnicos de la novela.

Cuando expuse anteriormente unas notas sobre la relación entre ideología y literatura pensaba, sobre todo, en el Eusebio. Si de una novela ideológica se trata, habrá de resolverse atendiendo, fundamentalmente, a su eficacia pragmática. Como tal novela ideológica, los elementos discursivos del Eusebio deberán estar encaminados a facilitar la aceptación de las premisas a las que acabo de hacer referencia, y ello en distintos niveles.

A los planteamientos generales de la educación responde, en primer lugar, la estructura de la novela. La adecuación entre estructura ideológica y estructura discursiva resulta pedagógica y eficaz. El aprendizaje perfecto debe comenzar, según los ilustrados y específicamente según Montengón, por la enseñanza de la moral y el conocimiento de un oficio; seguirán las ciencias y las lenguas. El viaje útil ayudará a poner en práctica los conocimientos anteriores y, a través del contacto directo con distintos países, perfeccionará y ampliará las ideas acerca de su

\footnotetext{
35 "Vida y obras de don Pedro Montengón y Paret», tesis doctoral inédita, Madrid, 1947 (cito por Caso González, ob. cit., pág. 590), y «Noticia bibliográfica sobre las obras de don Pedro Montengón y Paret (1745-1824)», en Homenaje a la memoria de don Antonio Rodríguez Moñino. Madrid, Castalia, 1975, págs. 195-204, pág. 196.

36 Caso González, ob. cit., pág. 590. Juan Andrés: Origen, progreso y estado actual de toda lileratura, Madrid, 1787, IV, pág. 525.
} 
historia, su arte o sus costumbres. Finalmente, el sujeto verificará, en su vida de madurez, los resultados de su educación.

Dividido en cuatro partes, el Eusebio va marcando perfectamente estas etapas. La primera de ellas recoge el aprendizaje moral y artesanal de Eusebio, y a continuación el científico y lingüístico, de modo que Eusebio modesto, frugal, dócil y comedido, se prestó mucho mejor a la nueva enseñanza de su maestro (pág. 216). Corresponde esta etapa a su niñez y adolescencia. Se incluye en ella su educación amorosa hasta el definitivo enamoramiento de Leocadia, la mujer virtuosa, y los preparativos del viaje.

La segunda y tercera parte recogen, respectivamente, los viajes a través de Inglaterra y Francia. Además de completar la formación de Eusebio, en diferentes episodios puede observarse cómo el personaje puede ir poniendo en práctica su educación. Así, por ejemplo, se comprobará la utilidad del dominio de su oficio, que le salva de la miseria en Londres, y se corrobora la eficacia de su educación amorosa al superar un falso enamoramiento en Inglaterra. Con la llegada a España y la muerte de Hardyl se da por concluido el aprendizaje de Eusebio, que ya ha tenido alguna ocasión de ejercer, a su vez, de guía moral con respecto a otros personajes.

Será sin embargo en la parte cuarta, durante su primera estancia en España, cuando Eusebio ponga definitivamente en práctica los conocimientos teóricos. Regresará a América para casarse y educará a su esposa y a su hijo. Una segunda vuelta a España con Leocadia servirá para que ésta, a su vez, tenga ocasión de poner en práctica las enseñanzas de Eusebio. El lector tiene asi la oportunidad de comprobar la eficacia del programa educativo propuesto por Montengón, pues queda demostrada en la diégesis. Las enseñanzas de Hardyl en la parte primera han hecho de Eusebio un modelo que será admirado en Inglaterra, Francia, España y Pensilvania.

Para que la composición de la novela, de esta manera planteada, no resulte excesivamente árida, Montengón recurre a diversos artificios. En primer lugar, la novela se dota de cierta intriga que, junto con los continuos viajes, tiene alguna semejanza con la de la novela bizantina. A lo largo del relato se van dejando pistas al lector, pero la intriga, que sirve a modo de eje de la historia de Eusebio, no se descubre hasta el final. El elemento fundamental de esa intriga es la identidad del educador, Hardyl, que resulta ser tío de Eusebio y cuyo verdadero nombre es Eugenio. También el padre de Leocadia declara haberle sido robado un hijo, que encontrarán en Sevilla al final de la novela.

Estructura argumental idónea para la exposición de un amplio registro de elementos ideológicos es el viaje, que responde por otra parte al cosmopolismo tan del gusto de los ilustrados. Se trata de un viaje eficaz en el sentido educativo. Indica García Lara que la geografía, las costumbres, las creencias y hasta la historia reciente de la Pensilvania, Inglaterra, Francia o España desfilan ante los ojos del lector al que se pide, por tanto, un mínimo de educación histórica para lograr esa aspiración ilustrada del «viaje útil» ${ }^{37}$. Hardyl instruye a Eusebio no para que

37 Introducción a la edición citada, pág. 58 
se limite a mirar superficialmente, sino para que ejercite una observación detenida, seguida de la reflexión, que es la que ha de hacer de Eusebio conocedor comprensivo de las costumbres, las leyes o las lenguas de otros países. Procurará, además, sacar provecho de su aprendizaje aplicando los nuevos conocimientos (sobre todos los relativos a la industria) a su entorno (págs. 513-515). En suma, dice el narrador, no hay mejor maestro que el mundo mismo para quien lo estudia (pág. 516).

El viaje, además, proporciona variedad y agilidad al relato: distintos escenarios, personajes y episodios se suceden ante los ojos del lector, suavizando las en ocasiones prolijas digresiones ideológicas.

También para dotar de agilidad a la narración, Montengón intercala numerosos episodios independientes - un recurso que también utilizaria en El Antenor y el Mirtilo-. Y lo hace deliberadamente, demostrando conocer bien los resortes narrativos y los medios de que dispone para adoctrinar y mantener al mismo tiempo la amenidad. Cuando la censura prohibe el libro en 1803, un escrito titulado Examen analítico de la censura de $N$. sobre el «Eusebio», que la crítica no duda en atribuir al propio Montengón, refuta las objeciones del censor, entre ellas la planteada a la inclusión de estos episodios accidentales. En este escrito Montengón defiende, teóricamente, la necesidad de enseñar al hombre la verdad desnuda, pero aderezándola, y la conveniencia de utilizar para ello, como vehículo adecuado, el relato novelesco: Así es que en todos tiempos se ha conocido la necesidad de endulzar los bordes de la copa en que se le propinaban los saludables preceptos de la enseñanza moral, y quien supo amonestar uniendo con más primor lo útil a lo placentero, fue siempre reputado como el mejor Maestro. De aqui han nacido los Apólogos, los Poemas, Alegorías, Novelas y varios otros géneros de composiciones, destinadas entre todas las Naciones y por todas las sectas a grabar profundamente y con agrado en el ánimo de los creyentes las máximas de cada una (...). Las parábolas sin las que no hablaba nuestro Redentor, y por medio de las cuales inculcaba a sus discípulos los misterios más sacrosantos y la doctrina más sublime ¿no demuestran hasta la evidencia que la suprema verdad contempla útil el pintar bajo el velo de una graciosa historieta la virtud y la Religión misma a los débiles mortales? ¿Y qué otra cosa hicieron más que seguir las huellas de su divino Maestro los que posteriormente han publicado obras de estilo romancesco, consagrados a la educación del género humano? Una por mil citaremos, y sea el «Telémaco» del buen Fenelón.

Más adelante demuestra conocer, además de esta eficacia pedagógica, la técnica y propósito de los episodios. Afirma que en todas las obras del género poético, o del romancesco, como la de "Eusebio», entran ciertos cuentos subalternos y accesorios al cuento principal, que los inteligentes llaman «Episodios». Su objeto es amenizar el escrito por la variedad y probar algunas verdades de las enunciadas en el cuerpo de la obra o relativas de cualquiera manera a los fines del Autor. Los personajes que se inducen hablando en el episodio a cuya acción se refiere, en cuanto destinados a probar o confirmar alguna verdad, deben presentar modelos tan perfectos como el héroe principal ${ }^{38}$.

38 «Pedro Montengón y su novela El Eusebio», cit. págs. 172-173 y 175. 
Hay, en efecto, diversos episodios en el Eusebio. Para "amenizar el escrito» aún más, su modo de inclusión es también variable: unos están narrados por personajes que los protagonistas conocen (la historia de John Bridge, por ejemplo); otros los relata Hardyl (la historia de Omfis y Earina); los más se involucran en la acción principal y se ensartan en el decurso de los acontecimientos (la historia de Gabriela o Adelaida).

Los episodios, por otra parte, sirven para presentar un amplio muestrario de personajes de la más variada índole moral y social. El recurso permite, pues, la representación de todos los vicios y todas las virtudes y diversas situaciones y condiciones humanas. A su función estrictamente narrativa, la de proporcionar variedad y agilidad al relato, se superpone, desde luego, la ideológica. Así, por ejemplo, tras una larga disertación por parte de Hardyl en torno al sentimiento amoroso instintivo, se narra una historia ejemplificadora, la de Omfis y Earina, que sirve para probar los riesgos que conlleva un matrimonio precipitado, pasional y ajeno a la virtud. A continuación, un nuevo discurso ideológico que ensalza las excelencias del amor virtuoso tiene su correlato en otra historia opuesta a la primera, la de Isidoro. La eficacia didáctica queda asegurada no sólo por el contraste entre las dos disertaciones, sino también por los contrarios resultados del desenlace de las historias. La conclusión moral de Hardyl, basada en esos ejemplos - uno de ellos, el de Isidoro, «real»- cierra definitivamente el tema: Más sólo he querido darte un bosquejo de la vida dichosa que llevaba con Dorotea, por prueba y ejemplo de los felices casamientos que, aunque raros, se ven con todo en el mundo. Y si no se cuentan más frecuentemente, la culpa está de parte de aquéllos que los contraen faltos de los principios de la filosofia moral (pág. 261).

Montengón es consciente también de los recursos pragmáticos a los que puede recurrir para asegurar la eficacia de la enseñanza en el oyente (Eusebio) o el lector. Hardyl reclama a menudo su atención -Oye (paǵ. 239), Escucha todavía (pág. 241) - o le exige un juicio - iParécete, Eusebio, que pudieran tener tan desastrado fin tan tiernos y ardientes amores? (pág. 243) - . Con el fin de justificar la larga extensión de las digresiones e incluso la abundancia de historias ejemplificadoras, el propio Hardyl, ante la posibilidad de que Eusebio esté cansado, sugiere dejar el relato. Son ambos trasunto del narrador y el lector. Para arrastrar a este último, Eusebio responde: No, no (...), proseguid; dadme este placer, pues os aseguro que lo tendré en escucharlo por largo que sea (pág. 246).

También, según la idea de Montengón, los protagonistas de estos relatos se ofrecen como paradigmas, positivos o negativos, destinados a probar o confirmar alguna verdad: Bridge representará al hombre que no domina sus pasiones; Omfis y Earina sirven como modelo del amor precipitado y mal entendido; su contrapunto será Isidoro, que basa el amor en la virtud; Ios padres de Gabriela son el prototipo de la paternidad autoritaria y egoísta, mientras que los de Adelaida son trasunto de aquéllos que maleducan a sus hijos por tener presente, ante todo, la ambición y la vanidad, etc. Es de notar que no queda ningún cabo suelto en la novela: los personajes que desaparecen en determinado momento de la historia reaparecerán más tarde para verificar, con la recompensa o el castigo que hayan recibido, las consecuencias de su actitud: asi Orme, que termina en la horca, o Bridge, que recoge los beneficios de los consejos que recibiera de Hardyl. 
Si esto ocurre con los personajes de los episodios accesorios, con mayor motivo ha de cuidar a los protagonistas de la acción principal, que, según Montengón, debían presentar «modelos perfectos». Los protagonistas están, en efecto, también tipificados en virtud de una premisa moral, respondiendo cada uno a un esquema de conducta. La tipificación se percibe incluso en el simbolismo del nombre de los dos personajes principales. Eusebio ( $\varepsilon \cup-\sigma \varepsilon \beta \eta ́ \varsigma$, en griego, que significa puro, de recta conciencia, cumplidor del deber) y Hardyl, cuyo verdadero nombre resulta ser Eugenio ( $\varepsilon v-\gamma \varepsilon v \eta \dot{s}$, en griego: bien nacido, noble, generoso, virtuoso).

De entre los restantes personajes con cierta entidad cabe destacar dos de ellos que Motengón utiliza para apoyar su eficacia didáctica. Susana, la madre adoptiva de Eusebio, se muestra reacia a los métodos de Hardyl. Representa en parte las objeciones que el lector pudiera oponer a tales métodos. Susana - y el lectordeberán reconocer su utilidad. Así terminará ella misma comprobando los beneficios que reportará a Eusebio dominar un oficio, práctica a la que era contraria. Leocadia, la mujer de Eusebio, se utiliza también como trasunto del lector, ejemplificando una conciencia recta y virtuosa, pero deformada por la mala educación ya que desconoce la filosofía moral (págs. 927-928). Su perfeccionamiento es ostensible al seguir los consejos de Eusebio. El lector medio - la lectora, en este caso- puede identificarse con un personaje que reúne una mezcla de virtudes y defectos; podrá entonces, igual que ella, aprovechar la educación que recibe. También Leocadia, como Susana con respecto a Hardyl, se opone a algunos métodos de Eusebio, como la educación del recién nacido, al que Eusebio aísla e ignora para hacerlo fuerte desde la cuna; también, al igual que Susana, terminará reconociendo su eficacia.

Otra figura más requiere algún detenimiento, pues es prueba inequivoca de que Montengón conoce los resortes del relato. En el Examen analítico al que hice referencia, Montengón afirma que, además de los personajes «modelo», cuya misión es defender un postulado ideológico, pueden tener cabida en el relato otro tipo de personajes. Más en los relatos de pura narración - dice-en que no se ofrecen al lector como ejemplos dignos de imitación, las leyes de la composición no son tan rigurosas, antes dan facultades amplias al compositor para hacer contrastar los vicios con la virtud, a fin de que el brillo de ésta resalte más y más, como se ve en todas las piezas de teatro con ciertos papeles subalternos ${ }^{39}$. Esta afirmación, válida para los personajes con rasgos negativos, tiene otra aplicación. Se trata de un personaje que no encuadra exactamente en un patrón negativo ni positivo, en el que hace gala Montengón de esa libertad compositiva a la que él mismo alude y que puede desempeñar en la novela el mismo papel que el «gracioso" en el teatro, como también indica Montengón. Es el criado Gil Altano, andaluz que salvó a Eusebio del naufragio y que le sirvió en adelante. Se caracteriza, con algunos rasgos picarescos, por su vivacidad y humorismo, por su lenguaje popular y por aceptar las comunes creencias del vulgo (duendes, brujas, apariciones y supersticiones).

39 fdem, pågs. 175-176. 
Funciona como contrapunto humorístico, pero no por ello deja de contribuir a la finalidad ideológica de la novela: desde esta perspectiva humorística se reconocen también las virtudes de los personajes y se ensalza la tolerancia, cuyos efectos, por lo tanto, no sólo han de ser percibidos por los instruídos (pág. 99). La figura de Altano posee, pues, una función narrativa pero también ideológica.

Con todo, su utilidad no se limita a esto. Montengón, gracias a Altano, puede introducir un registro realista y costumbrista en la novela, y no sólo por determinadas escenas que protagoniza - la del mesón, en la que le roban el coche de caballos (II, 3) - o los relatos populares que cuenta - el del mago Trigueros (III, 3) - , sino por su lenguaje popular, que contrasta con el tono sentencioso y elevado de los protagonistas. Altano, al interrumpir el relato con detalles y descripciones costumbristas y con los resortes del habla popular, enoja a Hardyl, cuyos reproches pueden considerarse como una justificación de Montengón, que no considera útiles para su propósito ideológico las descripciones minuciosas ni la prolijidad en el simple relato de los hechos (a pesar de que, según el decoro, nada de esto desentona en boca de Altano) pero que las introduce porque forman parte de los fragmentos de «pura narración» que proporcionan amenidad al relato: ; Válgame el cielo, dijo aqui Hardyl, por cuentos eternos e insulsos! ¿A qué viene tanta menudencia y tanto dije y dijo y tornó a decir y responder, ni esos brincos y descripciones, que no montan un bledo? (pág. 440). La justificación por el detallismo descriptivo aparece en más ocasiones, y no sólo con referencias a Altano. Sin embargo, sí es este personaje el que asume el registro lingüistico popular como un elemento más de la variedad de la novela. En ese sentido, cabe señalar la sátira de la elocuencia sagrada, al estilo del padre Isla, en la parodia de un sermón plagado de cultismos y comparaciones reiteradas que no contribuyen sino a la oscuridad del lenguaje (págs. 760 y ss.).

Hay que entender, además, la figura de Altano como uno más de los elementos realistas de la novela, que frente a los modelos tradicionales rechazados en el XVIII se inserta en una realidad concreta y reconocible para el lector, con numerosas referencias verificables. Tal realismo es imprescindible para garantizar la eficacia ideológica, y Montengón es consciente de ello. Así, tras la historia de Omfis y Earina narra otra basada en un personaje al que dota de realidad - Isidoro, al que Hardyl menciona como su amigo- y que sitúa en un entorno cercano. Dice Hardyl: Esto me trae a la memoria el caso de un dichoso casamiento; puedes creer que no lo tomo del tiempo de Filemón y Baucis. Tales historias son demasiado lejanas para que hagan impresión en nuestros pechos. El caso es reciente, pues es de un joven amigo mío, el cual contribuyó también para que yo escogiese la vida que llevo (pág. 246).

Si los elementos discursivos tienden a cerrar las posibles fisuras interpretativas, a convertir la novela en una obra cerrada en la que el mensaje sea unívoco, el papel fundamental lo desempeña el narrador, siempre como representante, en el discurso, del autor, de quien parte la voluntad didáctica. En la práctica discursiva, el sujeto que la activa ha de manifestar su presencia de forma inequivoca, si ha de transformarse en agente ideológico ${ }^{40}$. Para poder ejercitar su presión

40 Cf. Carlos Reis, ob. cit., pág. 35. 
ideológica en el relato, las formulaciones genéricas han de ser mostradas como registros de la subjetividad, cuya manifestación más efectiva es el discurso valorativo. Y precisamente las largas digresiones ideológicas y valorativas son las que caracterizan la novela, concebida en función de su utilidad. Esto explica la necesidad de justificar las descripciones detallistas, que no se rechazan en absoluto pero que el autor intuye como extemporáneas en la novela ideológica, y el hecho de que, en diálogos de frases breves y rápidas, de «pura narración» según el propio novelista, la disposición de éstos sea similar a la teatral, suprimiéndose las indicaciones previas del narrador al disponer la participación de los hablantes.

Hardyl es, sobre todo mientras dura la educación de Eusebio, quien asume la misión ideológica, dirigiendo a éste directamente sus enseñanzas. Es trasunto evidente del autor, que interviene para corroborar, en total connivencia, sus ideas, juicios y métodos educativos (por ej., pág. 215). Sus asentimientos llegan a ser, en ocasiones, innecesarios y repetitivos: el mensaje se hace redundante desde el punto de vista ideológico $\mathrm{y}$, por ello, absolutamente cerrado.

La voz de Hardyl va siendo sustituida por la del narrador, sobre todo desde que se da por concluida la educación de Eusebio en Pensilvania, del mismo modo que la mayor carga de didactismo pasará a ser responsabilidad de Eusebio cuando éste, ya en el último libro, perfectamente educado, asuma la instrucción de Leocadia y su hijo. La función del narrador será, desde el libro segundo, confirmar el acierto de las enseñanzas del preceptor y ejercer, del mismo modo que Hardyl lo hacia con respecto a Eusebio, esa presión educativa e ideológica sobre el lector. Por eso es ahora el narrador quien deduce las consecuencias morales que se desprenden del relato. Son numerosas las intervenciones en las que el narrador increpa directamente a los lectores, pero también al propio Eusebio, al que se dirige en segunda persona, utilizando a este último para influir, a través de él, en el ánimo del receptor.

El personaje, por otra parte, actúa en una sola dirección. Todas sus tentaciones serán vencidas. El modelo es unívoco, no presenta fallas. Para acercar la lucha interna de Eusebio al lector, con la intención de que éste se identifique con él y pueda comprobar que es posible la superación y la victoria moral, Montengón utiliza también otros procedimientos, como el de transcribir, a través de la voz del narrador, el pensamiento del protagonista, o bien presentar éste directamente, analizando sus propias reacciones, a través del monólogo.

Hacia el final de la novela, y para que el mensaje educativo no sea entendido por el lector como algo excesivamente teórico y lejano, Montengón hace figurar la novela como relato hecho sobre las memorias de Eusebio en una única alusión. Cuando Eusebio, una vez casado, se dedica al estudio, dice el narrador que ejercitaba al mismo tiempo su estilo, cuyos primeros ensayos fueron las memorias que dejó de su educación y viajes, que sirvieron de materiales para recopilar este trabajo, a quien se dio el título del nombre mismo de Eusebio, que no tenía en el manuscrito (pág. 926). Para García Lara, el marbete de «memorias» se debe, sobre todo, al temor de reconocer expresamente una obra como novela para no despertar recelos ante el descrédito del género, a la vez que recoge la tradición pi- 
caresca ${ }^{41}$. Sin embargo, podría interpretarse también como un recurso para potenciar la verosimilitud del relato, que intensificaría de este modo su eficacia ideológica. Por otra parte, el hecho de conferir al relato carácter autobiográfico está relacionado, desde luego, con los modos de la novela sentimental, popularizada por Richardson y Rousseau. En esta línea hay que entender también el sentimiento o sensibilidad de que hacen alarde los personajes, que, por otra parte, cumple una función pragmátia: la de conmover al lector y facilitar su identificación con los protagonistas.

La novela, pues, posee una estructura coherente que responde a los presupuestos de orden ideológico que la informan. Por eso no coincido con García Lara cuando considera la obra como un fracaso porque las tesis morales relegan al olvido a lo novelesco ${ }^{42}$. Nace de una inquietud ideológica, pero los procedimientos de Montengón, que se adecúan perfectamente a esta inquietud, consiguen la incorporación de los procedimientos narrativos a la intención didáctica. Sin aceptar el contexto cultural en el que surge, difícilmente podría entenderse una obra literaria.

En el año en que se publica el último tomo de Eusebio, 1788, aparece también otra novela: El Antenor. Se trata de un poema épico en prosa, de resonancias claśicas, que narra la historia del fundador de Venecia tomando como modelo a Virgilio. Según Fabbri, es la única adaptación hispánica de la tendencia europea al poema épico en prosa, que goza de gran popularidad en España a través de Fénelon, Florian, Marmontel, Lantier, etc., pero que no se cultiva ${ }^{43}$.

Resulta interesante el prólogo, en el que Montengón muestra sus intenciones y alude a la terminología narrativa. Distingue entre «historia» y «romance», a la vez que identifica «romance» y «epopeya» con un relato histórico deformado por la fantasia, esto es: novela. Afirma que si la historia del origen de los pueblos, como la de Roma, ha sido deformada por la fantasía popular hasta convertirla en leyenda, quien narra esta leyenda no hace "historia», sino "epopeya", creación literaria. En consecuencia, asegura contar la fundación de Venecia, al modo de Virgilio, en «romance», y no en «historia» ${ }^{44}$.

Hay, además, otras obras europeas, "poemas en prosa» de tono épico, en las que indudablemente se inspiró: Belisario (1766) y Los incas $(1777)^{45}$, de Marmontel, o Numa Pompilio (1786), de Florian ${ }^{46}$. Montengón da el título de «romance épico" también al Rodrigo, obra inspirada en la épica española. Puede deducirse entonces que Montengón otorga tal denominación a aquellas obras de inspiración épica en prosa, que por su tema pueden considerarse «epopeyas». Tal

41 Introducción, cit., pág. 62.

42 Idem, pág. 63.

43 Ob. cit., pág. 103.

44 El Antenor. Madrid, Imprenta de Sancha, 1788, 2 vols. (vol. I. págs. III-IV).

45 Según González Palencia, en esta obra se inspira Montengón para su Antenor; a su vez, Marmontel se basa en los Comentarios reales del Inca Garcilaso de la Vega ( «Pedro Montengón y su novela El Eusebion, cit., pág. 143).

46 Cf. Brown, ob. cit., págs. 9-10. 
vez Montengón está tratando de suplir el vacío que encuentra en la epopeya española cuando afirma en el Eusebio que éste no podía comprender cómo, siendo la lengua española tan grave y majestuosa, y por consiguiente tan propia de la tragedia, de la epopeya y de la oratoria, no tuviesen los españoles ni un sólo modelo en ellas (pág. 841).

Desde el punto de vista ideológico, se trata una vez más de una obra en todo acorde con los presupuestos de la Ilustración: presenta un modelo de monarca ilustrado, amante del progreso, virtuoso, moderado, justo y benevolente. Montengón, que se ocupa por los mismos años de Eusebio, pretende ahora exponer un nuevo modelo de conducta, esta vez centrada en la figura del rey, pero a través de un cauce formal diferente.

Todavía escribe otra novela educativa, ésta muy similar al Eusebio: Eudo$x i a$, hija de Belisario $(1793)^{47}$. Es una novela educativa con ingredientes sentimentales. Dado que se basa en un personaje histórico, Belisario, el general del emperador Justiniano, podría pensarse en su posible condición de novela histórica. Sin embargo, la recurrencia es un simple pretexto. Aprovecha la popularidad que habia proporcionado en España al personaje el éxito del Belisario de Marmontel (1767), muy conocido en la época, como lo demuestra la referencia de Cadalso en los Eruditos a la violeta. La obra del escritor francés responde a las características del siglo de las luces. Trata distintos temas ilustrados, sobre todo la tolerancia religiosa (lo que, al igual que al Eusebio, le acarrearía la censura de los teólogos de la Sorbona), y pretende representar la resignación y sabiduria moral del personaje en la adversidad. Montengón recoge tema, personajes e intención de Marmontel, escogiendo ahora como personaje central a Eudoxia ${ }^{48}$. La intención de Montengón es clara: si el Eusebio marcaba las pautas de la educación masculina, Eudoxia se convertirá en su réplica femenina. No sólo aprovecha Montengón el éxito de la obra de Marmontel: también el de su propio Eusebio. La tesis central de la obra es la necesidad inexcusable de dotar a las mujeres de ciencia moral y virtud, únicas armas capaces de proporcionar la felicidad incluso en la miseria: de aqui se desprende el consiguiente desprecio hacia el lujo, la vanidad y la riqueza.

De indudable influencia prerromántica es la gran dosis de «sensibilidad» que, como en otras novelas del autor, inunda la obra, haciéndola caer a veces en lo lacrimoso y melodramático. Puede entenderse también, por lo tanto, como novela sentimental, tendencia que habían popularizado en Europa, sobre todo, Richardson y Rousseau. El sentimentalismo, de todas formas, está moderado por la prudencia y el decoro clásico, como señala Fabbri, a la vez que las referencias a la naturaleza remiten no a un prerromanticismo exaltado sino a los esquemas racionales del pensamiento ilustrado ${ }^{49}$. A pesar de ello, predomina la intención

47 Cito por la edición de Barcelona, Juan Ignacio Jordi, 1815.

48 Fabbri puntualiza las diferencias con respecto a la obra de Marmontel (ob. cil, pảgs. 85 y ss.).

49 Ídem, pág. 93. 
moralizante y educativa. Pese a las escasas alusiones al catolicismo y las referencias frecuentes a la mitología clásica, el juicio positivo del censor Santos Díez González demuestra su carácter didáctico y su efectividad. Su objeto, dice el censor, es manifestar con el ejemplo de Eudoxia la necesidad que tienen las damas ilustres del estudio de la filosofía moral, para que con las sólidas máximas que aprendan, destierren aquellas preocupaciones que las inspira el mundo, y abracen constantemente la virtud y se hallen prevenidas para sufrir con fortaleza los reveses de la fortuna. Es loable, sin duda, el designio del autor; y lo es también la forma, o artificiosa constitución de la fábula, en que, conforme a su propósito, introduce en varios diálogos a Eudoxia, Domitila, aya suya; Maximio, caballero ilustre, pero pobre, que la pretende para esposa; Belisario y Antonina, padres de Eudoxia, en todos los cuales se pintan, respectivamente, virtudes y defectos morales, pero estos contrastados por la virtud a quien hace el autor, que siempre salga triunfante 50 .

No se le escapó al censor, según estas últimas observaciones, la estrategia narrativa de Montengón. La construcción de la obra, en efecto, se encamina a mostrar una tesis moral. Para ello, Montengón se basa en la evolución misma de los personajes, construidos como arquetipos: Domitila, prototipo de educadora en la virtud y la moral y réplica del Hardyl de Eusebio; Belisario, buen padre que se esmera en perfeccionar el talento de su hija con las luces y conocimientos de algunas ciencias, queriendo sacar en ella un particular modelo de educación, según el narrador (págs, 1-2); Antonina, representante de la ambición y la vanidad que, al no ser virtuosa, no puede soportar la desgracia de su marido y la suya propia y muere, como castigo frente a la felicidad de los restantes personajes. En medio de estos dos extremos, Maximio, individuo de naturaleza bondadosa pero que no posee la filosofía moral; por ello el lector, al igual que ocurría con respecto a Leocadia, puede identificarse con él: podrá aprender, al igual que Maximio, de las constantes enseñanzas de Belisario y Domitila y del ejemplo de Eudoxia.

Pero, además, Montengón adapta a su propósito educativo la forma narrativa. Las largas disertaciones sobre moral, virtud o filosofía se expondrán, para hacerlas amenas, a través de los constantes diálogos entre los personajes, siendo interrumpidos, en ocasiones, por la acción, y retomados más adelante, para proporcionar agilidad al relato. El narrador intervendrá también para certificar con su propio juicio las opiniones de los personajes o deducir conclusiones didácticas de determinados episodios. Otras veces interpela directamente al lector, conminándole a recoger la lección moral que del relato se desprende y justificando, en función de esa utilidad moral, la pintura a veces prolija de los acontecimientos. Después de recoger diversos temas gratos a los ilustrados concluye manifestando, al final de la novela, su propósito didáctico y la deducción moral. Si la novela puede considerarse «cerrada» por la univocidad de su interpretación, la intervención final del autor niega toda posible continuación o interpretación diferente a la que él mismo ofrece. Así, todos los elementos de la diégesis están al servicio, de una manera explícita, de determinadas premisas ideológicas: personajes, ám- 
bito geográfico y cultural, ... a la vez que las técnicas discursivas pretenden influir en el ánimo y la mente del receptor. Por ello la recurrencia sentimental incita al lector a lamentar las desgracias de los protagonistas e identificarse con ellas, facilitando así la identificación posterior con la actitud que éstos adoptan ante la adversidad: las instancias morales tanto de los personajes como del narrador le proponen el remedio para alcanzar la felicidad.

Parece posible pensar que Montengón da por concluido su ciclo educativo, y busca ahora nuevos cauces de expresión novelística para adaptarlos a la ideología ilustrada. Su siguiente novela, el Rodrigo, «romance épico» (1793) ${ }^{51}$, toma el tema histórico de la pérdida de España frente a los árabes. Puede considerarse, a pesar de intentos anteriores recogidos por Ferreras ${ }^{52}$, como la primera novela histórica española, cuya fecha de aparición quedaría entonces adelantada en veinte años: no sería la primera Ramiro, conde de Lucena, de Rafael Humara (1823), sino una novela del siglo XVIII ${ }^{53}$. No hay que olvidar que la recuperación de temas pertenecientes a la historia y la épica española no es exclusiva del romanticismo y su afición a los temas medievales. En el teatro dieciochesco, los temas neoclásicos (bíblicos o tomados de la antigüedad grecorromana, cuya réplica novelística pudiera ser el Antenor) van siendo sustituidos por la historia nacional, con connotaciones políticas. Si la Lucrecia, de Nicolás Fernández de Moratin (1762), no pudo representarse por sacar a escena a un tirano que ponia en entredicho la teoría política del despotismo ilustrado, los temas siguientes representarán la tiranía en el poder extranjero: se trata, por un lado, de popularizar la tragedia al tratar temas nacionales; por otro, de exaltar valores patrióticos, según la línea de actuación de los ilustrados, ponderando la imagen de una España que toma las armas en su defensa y no por ambición expansionista, dado que persistía en Europa el desprecio hacia la política imperialista de los Austrias. Se muestra una nación «reconquistadora» y no sólo de territorios, sino, en un nivel simbólico, del lugar que le corresponde en Europa. A este propósito responden Hormesinda (1770) y Guzmán el Bueno (1777), del propio Moratín; Pelayo (1769), de Jovellanos, Sancho Garcia (1771), de Cadalso y la Raquel (1775) de Garcia de la Huerta. René Andioc se ocupa de ello ${ }^{54}$. Destaca el tema de don Rodrigo, origen de la invasión árabe y la consiguiente reconquista. La figura de don Rodrigo va despojándose de culpa (la censura había sido dura con los ataques a la figura de un rey) y ésta pasa a don Julián; a la vez, como señala Menéndez Pidal, la figura

S1 Madrid, Imprenta de Sancha, 1793.

52 Ya desde finales del siglo XV hay obras que pueden confundirse con las crónicas; en el XVIII, antes de Montengón, señala Ferreras la anónima Ascanio, o el joven aventurero. Historia verdadera que contiene una relación que sucedió al principe Carlos Eduardo Stuart en el Norte de Escocia desde la batalla de Culloden... (1750), y la Historia verdadera del conde Fernán González, su esposa doña Sancha y los siete infantes de Lara, de Juan Rodríguez de la Torre (La novela en el siglo XVII. Ma. drid, Taurus, 1988, págs. 44 y ss., y La novela en el siglo XVIII, cit., págs. 24-25).

53 Coincido en ello plenamente con Fabbri, ob. cit., pág. 117. También lo defienden Brown y Ferreras en sus citados estudios.

54 Cf. René Andioc, Teatro y sociedad en el Madrid del siglo XVIII. Madrid, Castalia, 1976. 
de don Julián, causante de la invasión árabe, va dejando paso a la de don Pelayo ${ }^{55}$.

El Rodrigo recoge, pues, uno de los temas que exponen el pensamiento ilustrado. El protagonista se presenta como un tirano, aunque se culpa en gran medida, al igual que en la Raquel, a un mal consejero. De hecho, si Rodrigo termina cediendo, es a causa de una violenta pasión, lo cual permite introducir, también en la línea ilustrada, reflexiones morales que ponen de relieve sus perniciosos efectos. Rodrigo va mostrando paulatinamente sentimentalismo, generosidad y arrepentimiento, a la vez que se culpa a don Julián de hacer extensiva su venganza, que debiera ser personal, a toda la nación. Y, por otro lado, Rodrigo consigue su primera victoria frente a los árabes gracias a la intervención de Pelayo - la historia de cuyo nacimiento se cuenta en la novela- y los cántabros. En este tema insistiría todavía Montengón en 1820 en uno de los dos poemas épicos publicados en Italia ese año: La pérdida de España reparada por el rey Pelayo y $L a$ conquista de Mexico por Hernán Cortés.

Hay otro elemento ilustrado, que aparecia ya en el Eusebio, en la novela. El concepto de patria que expresa es esencialmente crítico, y esto a pesar del patriotismo de Filopatro, que dedica una de sus odas a uno de los responsables de su exilio, el conde de Aranda. No es diferente el patriotismo crítico de Cadalso, por ejemplo. La patria no ha de ser sólo el país de nacimiento, sino una tierra y una sociedad que tiende a procurar la felicidad, el bienestar y la cultura de sus habitantes. Así, Evanio, ultrajado y obligado a exiliarse a territorio árabe, dice: Patria es sólo aquella que asegura al hombre la vida, los bienes y la libertad (pág. 219).

Montengón declara en el prólogo al Rodrigo su intención de presentar la historia verdadera, sin los elementos de los que la ha adornado la tradición o la fantasía. Sin embargo, a pesar de su protesta de veracidad, la historia está absolutamente novelada. Recurre para ello a la relación amorosa entre Florinda, la hija de don Julián, y Evanio, hijo de Witiza. Pero hay, además, una serie de elementos fantásticos difíciles de encajar en la ideología ilustrada, que se opuso a ellos (y el propio Montengón lo habia hecho en el Eusebio y en la Eudoxia), tales como apariciones, visiones, presagios... No pueden justificarse si no es por el deseo de conceder a la obra un tono precisamente legendario. Ello viene a sugerir la idea de que su propósito de atenerse a la verdad histórica no es más que un recurso narrativo. Recordemos que en el Antenor había declarado contar no la historia, sino el romance. Montengón está escribiendo una novela.

Por eso puede considerarse el Rodrigo como la primera novela histórica española, incluso teniendo en cuenta la presencia de distintos ingredientes que aparecen también en el resto de su obra (sentimentalismo, moralización, bucolismo). A pesar del carácter romántico del género en el XIX y de la innegable influencia

55 Floresta de leyendas heroicas españolas. Don Rodrigo, el último godo (tomo III: La edad moderna). Madrid, La Lectura, 1928, págs. 16-17. El tema de don Pelayo es, además, muy conocido, como figura importante que es del romancero. Indica David Thather Gies que esa es la razón que mueve a Moratín a elegir el tema de su Hormesinda, popularizado en el decenio anterior por una epopeya de Alonso de Solis (Nicolás Fernández de Moratín. Boston, Twayne Publishers, 1979). 
de autores extranjeros, y sobre todo de Walter Scott, no hay que olvidar que Montengón fue muy leído en su época: su éxito alcanza la primera mitad del XIX. Aunque no he encontrado alusiones a él en novelistas de este siglo, no sería de extrañar que hubiera sido tomado como punto de referencia sobre todo cuando se intenta dotar de «originalidad» a la novela histórica escogiendo temas pertenecientes a la historia nacional.

Sigue el experimentalismo de Montengón en su última novela, informada también de algunos de los presupuestos ideológicos ya expresados en las anteriores: El Mirtilo, o los pastores trashumantes $(1795)^{56}$. En este caso, los recursos utilizados en virtud de su función ideológica se enmarcan en un cauce formal diferente, el de la novela pastoril. Tal hecho ofrece diferentes perspectivas en su justificación.

Por una parte, la poesía había recuperado las formas artificiosas del bucolismo hasta el punto de hacer de las anacreónticas una de las formas poéticas representativas de la segunda mitad del siglo. Si se considera, siguiendo a Avalle Arce, que la última novela pastoril española es de 1633 (Los pastores del Betis, de Gonzalo de Saavedra) ${ }^{57}$, hay que tener en cuenta, por otra parte, que este género seguía siendo muy popular, como defiende López Estrada ${ }^{58}$, y que cuenta en el XVIII con otras dos manifestaciones: La galatea segoviana. Pastores del Eresma (1795), de Francisco Fernández Merino, y Los enamorados o Galatea y sus bodas, de Cándido María Trigueros. Producción bien pobre es, y que podría extrañar en una época en la que las referencias pastoriles llegan a constituirse en auténtica moda literaria. Ferreras justifica dicha escasez por el didactismo imperante en el siglo, que no tiene cabida en la estructura de la novela pastoril ${ }^{59}$. En efecto, lo que Montengón hará será adaptar los moldes pastoriles a su intención didascálica. Si consideramos los cánones pastoriles como molde ideológico, nos remiten de inmediato a uno de los puntos del pensamiento ilustrado montengoniano: la oposición entre aldea y corte, o vida natural frente a corrupción. El marco geográfico y las intenciones de los personajes al optar por un tipo de vida bucólico resultan así claramente significativos.

El uso del esquema pastoril podría interpretarse, por otro lado, como una recurrencia a modelos ya fijados en un momento de decadencia creativa o como el intento de revitalizar un género narrativo caído en desuso pero todavía popular.

Me inclino a tener en cuenta las dos razones: Montengón, que intenta distintas posibilidades narrativas, pretende en efecto recuperar un género tradicional sirviéndose de la moda bucólica del momento; además, la misma estructura de la novela pastoril le sirve como cauce de expresión ideológica, aunque este intento de adaptación constate la imposibilidad de continuación del género.

56 Madrid, Imprenta de Sancha, 1795.

57 Cf. J. B. Avalle-Arce: La novela pastoril española. Madrid, Istmo, 1975, pág. 13.

58 F. López Estrada: Los libros de pastores en la literatura española. Madrid, Gredos, 1974, págs. 23 y ss.

59 Ob. cit., págs. 27-28. 
Así, la intención predominante es la de ensalzar la vida en contacto con la naturaleza, que preserva la pureza y favorece el desarrollo de la virtud frente a las vanidades de la corte. A esta idea, ya expuesta en la Eudoxia, se suma el concepto de la virtud natural del hombre, que sólo el alejamiento de la naturaleza puede pervertir. Los elementos de la tradición pastoril se convierten, entonces, en pretexto ideológico y en signo inequívoco de una Arcadia que es trasunto de la edad inocente, de la infancia y el contacto con la naturaleza.

El mito arcádico, como indica Fabbri, le sirve para exponer uno de sus puntales ideológicos: el hombre debe ser útil a la sociedad, pero debe a la vez aislarse de ella. Señala al respecto que Montengón se diferencia sustancialmente de otros cultivadores contemporáneos del género: se relaciona directamente con la tradición española e italiana del XVI y desdeña los motivos que mueven a los demás autores, llevados del deseo de reproducir una belleza clásica greco-latina o simplemente intentando encontrar un marco en el que insertar las a menudo mal entendidas teorías naturalistas rousseaunianas ${ }^{60}$.

Hace uso Montengón de todos los tópicos de la novela pastoril, aunque cabe hacer algunas matizaciones que confirman la opinión de que Montengón la utiliza como simple recurso y marco ideológico. Los pastores, siguiendo la tradición pastoril, no lo son sino por el traje; el mutuo reconocimiento de una superior calidad, y sobre todo, de cultura y aficiones literarias permite, por otra parte, justificar la sucesión de poemas a la que el hilo argumental sirve como simple pretexto. De hecho, la peripecia mínima de los pastores - la trashumancia y las vicisitudes derivadas del encuentro con otros personajes - no concluye. La novela termina con una abrupta e injustificada irrupción del narrador: cuando uno de los personajes va a comenzar su historia, el narrador dice: Lectores, no es culpa mía, si dexo de entreteneros con esta linda, e interesante historia (pág, 336). En ningún momento se alude a la posibilidad de continuarla. La peripecia pastoril, pues, no es más que un hilo para engarzar no ya historias, sino poemas y, sobre todo, temas de muy diversa indole que conceden un carácter ilustrado al libro: la amistad - tema tan caro a los ilustrados-, la agricultura, la ganadería (llega a proponerse una teoría económica para Extremadura), etc.

Los pastores, además, como dije antes, poseen una inusual formación literaria; por ello pueden introducirse observaciones literarias sobre la poesía o el teatro, también en la línea ilustrada. El intento de Montengón es el de recuperar una forma narrativa para convertirla en registro novelístico utilizable desde su posición ideológica. No importa tanto la peripecia como el pretexto para insertar las diversas digresiones. De ahi el uso frecuentísimo del diálogo, único procedimiento capaz de conferir dinamismo y agilidad a un relato en el que la acción no cuenta.

A la vez, el mito arcádico posee unas evidentes notas realistas. El marco clásico está adaptado a la realidad del siglo XVIII. Por eso Ferreras basa la originalidad de la obra en tratar la Arcadia ál modo realista, puesto que estamos en Andalucía, lo que le permite al siempre reformista y dieciochesco Montengón criticar el latifundismo, las consecuencias de la Mesta, y ya, en plena utopía, propo-

60) Ob. cit., pág. 129. 
ner soluciones al reparto de tierras. Tal novedad, inserta en un marco clásico, hace que Ferreras no acierte con la catalogación de la obra: novela pastoril, novela utópica, novela reformista o como se la quiera denominar ${ }^{61}$. La recurrencia a la verosimilitud o el realismo debe ser entendida teniendo en cuenta que, como todas las de Montengón, se trata de una obra de claras intenciones ideológicas, en este caso morales y también reformadoras. Por eso la novela no encaja en los cánones pastoriles: las referencias a la realidad rigurosamente contemporánea y la simplicidad argumental distan mucho de recoger la estructuración de un género «idealizante».

Montengón, basándose en un molde tradicional pero vinculado estética y culturalmente con su entorno cronológico, pretende adaptarlo a pautas ideológicas concretas. Tal es la causa de las modificaciones a las que debe someter el discurso. Pueden corroborarse así las profundas implicaciones entre información ideológica y discurso literario.

En este caso, Montengón encuentra un camino cerrado. O, por mejor decir, es él quien lo cierra al escribir la última novela pastoril de la literatura española. Determinadas peculiaridades técnicas de la novela pastoril son subvertidas en función de la efectividad ideológica del mensaje, mientras que se mantienen aquéllas que pueden resultar útiles a la exposición de la ideología deseada. Pero la estructura de la novela pastoril no admite esa subversión: estaba ya rigidamente configurada en la tradición; las modificaciones, por otra parte, no permiten la continuidad del género al desposeerlo de muchos de sus integrantes estructurales.

La presencia de abundantes elementos sentimentales en la totalidad de sus novelas lleva a plantearse el prerromanticismo de Montengón. Para Santiago García Sáez el Eusebio es, incluso, la primera novela romántica española ${ }^{62}$. Tal afirmación ha de ser, evidentemente, matizada. En principio, parece intuirse una peligrosa identificación en las teorias de Garcia Sáez entre romanticismo y prerromanticismo. Baste recordar con cuánto tacto la crítica ha tratado el término por su denominación «a posteriori». Sáez no entiende el espíritu y el trasfondo ideológico del romanticismo cuando interpreta el suicidio de don Álvaro en la obra del duque de Rivas como un castigo - o autocastigo - achacable a su falta de virtud: la virtud habria de ser entendida, desde este punto de vista, como una de las características ideológicas del prerromanticismo y el romanticismo; el castigo de don Álvaro sería equiparable al que reciben, en el Eusebio, Orme, Blund, Omfis, don Felipe..., personajes «no virtuosos». Pasa por alto García Sáez el problema del destino o el inconformismo del hombre romántico con el mundo, que le lleva al suicidio, a la frustación, y, en otros casos, como el de Espronceda, a la rebeldía y la ruptura de las convenciones morales y sociales. Por otra parte, la virtud, según Montengón, sólo se alcanza con el control de las pasiones, y el romanticismo preconizaba su absoluta libertad. El sentimiento amoroso, en el Eusebio, está sometido a la virtud. Otros elementos, como las visiones o augurios, que García Sáez interpreta como románticos, son criticados en la novela como fruto

61 Ob. cit., pág. 23 .

62 Montengón, un prerromántico de la Ilustración. Caja de Ahorros de Alicante, 1974, pág. 174. 
de la superstición y la ignorancia; si aparecen en el Rodrigo es porque se trata de una novela histórica, a la que había que proporcionar el aire legendario que Montengón justifica en el prólogo ${ }^{63}$.

Sentimiento y razón, o sentimiento y moral, por otra parte, no tienen por qué excluirse. Como bien indica Hazard, si el sentimental volvió resueltamente la espalda al filósofo, el filósofo le tendió tímidamente la mano. El filósofo fue elocuente, ésta fue su manera de ser lírico; no desdeñó poner en trémolo su voz. El filósofo tuvo indignaciones patéticas, y, por muy enemigo que fuese del entusiasmo, entusiasmos espectaculares por la virtud ${ }^{64}$.

Los indudables elementos prerrománticos de la obra de Montengón no hay que entenderlos de manera totalitaria. El prerromanticismo es una de las notas que configuran el conglomerado de tendencias de la Ilustración que, en efecto, va preparando la evolución hacia nuevas formas de entender el mundo y nuevas maneras literarias. Por eso, el hecho de que Montengón recoja también esos elementos - y la traducción de Fingal y Temora es, en este sentido, muy significativa- le presenta como un perfecto ilustrado y, a la vez, como un hombre de transición.

Finalmente, me parece obvio que la figura de Montengón resulta imprescindible en el panorama literario del siglo XVIII español, gracias a él no tan vacío, y esto, como he tratado de mostrar, por varias razones.

Su cosmopolitismo, sus inquietudes filosóficas y estéticas, de las que es buena prueba la traducción de los poemas ossiánicos, su afán enciclopedista, su intento de convertir la literatura en vehículo de transmisión de los ideales ilustrados, su preocupación por el estado de la cultura, la economía o la sociedad españolas, le convierten, a pesar de su exilio, en una de las más significativas figuras del conjunto de escritores ilustrados del reinado de Carlos III.

Además, y por lo que se refiere a la narrativa, su mérito es indiscutible. Su obra supone una evidente consciencia de la necesidad de revisar los procedimientos novelísticos. De ello da fe su insistencia casi experimental en distintos moldes narrativos: la novela épica de tendencia neoclásica (el Antenor), novela educativa y moral y novela sentimental, de indudable influencia francesa (Eusebio y Eudoxia), el intento de recuperación de la novela pastoril y su adecuación a la ideología ilustrada (El Mirtilo), y una novela histórica que puede considerarse como la instauración del género en la literatura moderna, inscrita también en el marco ideológico de la Ilustración (el Rodrigo)...

Como señala Fabbri, su adhesión a la Ilustración le empuja a probar todos los géneros literarios buscando el mejor medio para rendir un servicio a la comunidad. Y lo encuentra en la novela, que cultiva a pesar de que en España no estaba bien considerada, demostrando su eficacia como método de divulgación de ideas ${ }^{65}$ a la vez que se presenta como un perfecto conocedor de las técnicas na-

63 Ídem, págs. 127 y ss., 169 y ss.

64 Ob. cit., pág. 311.

65 Ob. cit., págs. 42-44. 
rrativas. Todo ello sin contar con cuánto de innovador supone su obra como introductora de las más avanzadas corrientes europeas.

Además, el Eusebio, a pesar de su carga ideológica - que es, por otra parte, la que la motiva-, posee características capaces, en su construcción y su variedad, de convertirla en una auténtica novela, que rompe con el rechazo del siglo hacia el género y que lo instaura como una forma literaria de pleno derecho. Si su estructura y sus elementos se adecúan a una función ideológica, Montengón lo hace con acierto y efectividad. Por otra parte, supera en variedad y dinamismo a las novelas morales al uso, a la vez que sienta las bases de un realismo que nada tiene ya que ver con las fantasías imaginativas, inadecuadas en el contexto dieciochesco, de las tendencias narrativas que procedían del XVII. 